\title{
Chapter16 \\ Radiocesium Concentrations and Body Size of Freshwater Fish in Lake Hayama 1 Year After the Fukushima Dai-Ichi Nuclear Power Plant Accident
}

\author{
Kaori Takagi, Shoichiro Yamamoto, Keishi Matsuda, Atsushi Tomiya, \\ Masahiro Enomoto, Yuya Shigenobu, Ken Fujimoto, Tsuneo Ono, \\ Takami Morita, Kazuo Uchida, and Tomowo Watanabe
}

\begin{abstract}
We measured radiocesium $\left({ }^{134} \mathrm{Cs}+{ }^{137} \mathrm{Cs}\right)$ concentrations in five freshwater fish species in Lake Hayama, Fukushima Prefecture, 1 year after the Fukushima Daiichi Nuclear Power Plant (FNPP) accident in March 2011. The five species included bluegill (Lepomis macrochirus), Carassius spp. (Carassius auratus langsdorfii and Carassius cuvieri), Japanese dace (Tribolodon hakonensis), largemouth bass (Micropterus salmoides), and smallmouth bass (Micropterus dolomieu). We observed a "positive size effect" for radiocesium concentrations in fish muscle, but the coefficient of determination was low for bluegill, Carassius spp., and Japanese dace. In contrast, the coefficient of determination was high for the exponential relationship between body size and radiocesium concentrations in largemouth and smallmouth
\end{abstract}

\footnotetext{
K. Takagi $(\square)$

Marine Biological Research Institute of Japan Co., LTD,

4-3-16, Yutaka, Shinagawa, Tokyo 142-0042, Japan

S. Yamamoto $\bullet \mathrm{K}$. Matsuda

National Research Institute of Aquaculture, Fisheries Research Agency,

2482-3 Chugushi, Nikko, Tochigi 321-1661, Japan

e-mail: ysho@affrc.go.jp
}

A. Tomiya $\bullet$ M. Enomoto

Fukushima Prefectural Inland Water Fisheries Experimental Station,

3447-1, Inawashiro, Maya, Fukushima 969-3283, Japan

Y. Shigenobu $\bullet$ K. Fujimoto $\bullet$ T. Ono $\bullet$ T. Morita

National Research Institute of Fisheries Sciences, Fisheries Research Agency,

2-12-4, Fukuura, Kanazawa, Yokohama, Kanagawa 236-8648, Japan

K. Uchida

Fisheries Research Agency, 2-3-3, Minatomirai, Nishi, Yokohama, Kanagawa 220-6115, Japan

T. Watanabe

Tohoku National Fisheries Research Institute, Fisheries Research Agency,

3-27-5, Shinhama, Shiogama, Miyagi 985-0001, Japan

e-mail:wattom@affrc.go.jp 
bass. The geometric mean radiocesium concentration in each body size class was generally higher for carnivorous fish than for omnivorous and herbivorous fish.

Keywords Bluegill $\bullet$ Carassius spp. $\bullet$ Japanese dace $\bullet$ Largemouth bass $\bullet$ Nuclear accident $\bullet$ Positive size effect $\bullet$ Radiocesium concentration $\bullet$ Smallmouth bass

\subsection{Introduction}

The Fukushima Dai-ichi Nuclear Power Plant (FNPP) accident released a large concentration of nuclides, including ${ }^{131} \mathrm{I},{ }^{134} \mathrm{Cs}$, and ${ }^{137} \mathrm{Cs}$, into the atmosphere (Butler 2011; Chino et al. 2011). The Tokyo Electric Power Co. (2012) estimated the total amount of ${ }^{131} \mathrm{I},{ }^{134} \mathrm{Cs}$, and ${ }^{137} \mathrm{Cs}$ released during March 2011 to be approximately $500 \mathrm{PBq}$, approximately $10 \mathrm{PBq}$, and approximately $10 \mathrm{PBq}$, respectively. Because the half-life of ${ }^{137} \mathrm{Cs}$ is relatively long (30.2 years), contamination of the ecosystem is expected to be long lasting. Following the Chernobyl nuclear power plant accident, research showed that the chemical composition of the water (e.g., potassium levels) and the rate of circulation or turnover of water in freshwater systems affects the bioaccumulation of radiocesium in fish (Elliot et al. 1992; Saxén and Koskelainen 1992; Rask et al. 2012). In addition to these environmental factors, fish body size is often correlated with radiocesium concentrations in fish (Elliot et al. 1992; Koulikov and Ryabov 1992; Smith et al. 2002). Fish body size may be a proxy for age and life stage, with the latter being associated with differences in traits such as feeding ecology and metabolism. The excretion rates for radiocesium are higher in younger age groups than in older age classes. Furthermore, the decrease in radiocesium concentrations in water over time also results in lower radiocesium levels in younger fish (Kryshev and Ryabov 2000). Under these conditions, it is likely that radiocesium levels in fish will be a positive function of size.

As described in Chapter 15, the Fisheries Research Agency has conducted radiocesium monitoring of freshwater fish, lake water, sediment, and plankton in three lakes (Lake Akimoto, Lake Tagokura, and Lake Hayama) in Fukushima Prefecture since 2012. Lake Hayama (Fig. 16.1), the lake nearest to the FNPP among the three lakes, is a small artificially dammed lake ( 60 m maximum depth, $36.2 \times 106 \mathrm{~m}^{3}$ gross capacity of reservoir) in the Mano River system. This lake is located within a $30-50 \mathrm{~km}$ radius of the FNPP. The lake is also located in the area that was subject to high levels of radiocesium deposition $\left(\sim 300-600 \mathrm{kBq} / \mathrm{m}^{2}\right)$ in the period to 28 June 2012 (Ministry of Environment 2012a) as it was in the pathway of the radioactive plume from the FNPP. Indeed, Lake Hayama received the highest deposition of radiocesium among the lakes that are locally important for recreational fishing.

The concentration of radiocesium decreased in the water of Lake Hayama between the accident and 2012 (Chap. 15). Thus, we hypothesized that there would be a positive relationship between radiocesium concentrations in fish and fish body size in Lake Hayama. To test this, we measured radiocesium concentrations in individuals from the five dominant species in Lake Hayama in 2012, including bluegill (Lepomis macrochirus), Carassius spp. (Carassius auratus langsdorfii and Carassius cuvieri), Japanese dace (Tribolodon hakonensis), largemouth bass (Micropterus salmoides), and smallmouth bass (Micropterus dolomieu). 
Fig. 16.1 Location of collection sites in Lake Hayama

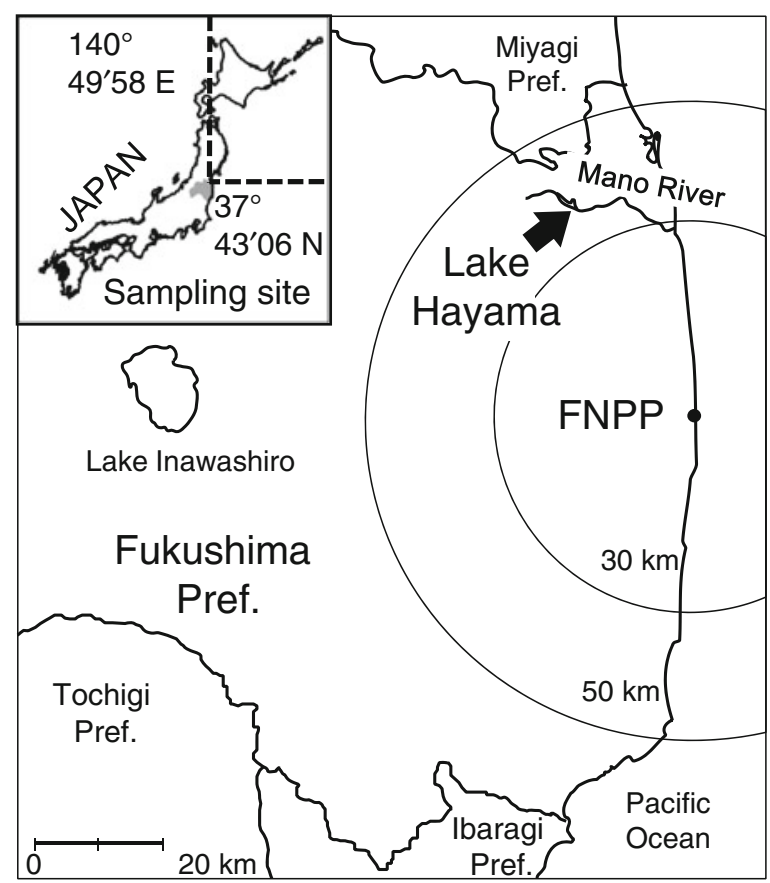

\subsection{Fish Species and Lake Water}

The five dominant fish species in Lake Hayama (bluegill, Carassius spp., Japanese dace, largemouth bass, and smallmouth bass) were collected by gillnet during 2012 (see Chapter 15). Bluegill, largemouth bass, and smallmouth bass are invasive species. These three species have been observed in lakes and rivers in Fukushima Prefecture since the 1990s. Smallmouth bass were the most dominant species in our surveys in 2012. Largemouth bass and smallmouth bass are carnivorous whereas bluegill, Carassius spp., and Japanese dace are omnivorous, and Carassius spp. is also herbivorous. Although there are few biological data for Lake Hayama, the five species we collected typically live for several years, so it is likely that some of the fish we collected were exposed to the fallout at the time of the accident in 2011.

The environmental characteristics of Lake Hayama are described in Chapter 15. The concentration of radiocesium in the surface water of Lake Hayama was 89 $\mathrm{mBq} / \mathrm{l}$ from September to November 2012 (Table 15.2). According to the Ministry of Environment (2011), ${ }^{134} \mathrm{Cs}$ and ${ }^{137} \mathrm{Cs}$ levels had declined to less than $1 \mathrm{~Bq} / \mathrm{l}$ by September 2011 in the surface water of Lake Hayama whereas levels at the bottom of the lake were 10 and $12 \mathrm{~Bq} / \mathrm{l}$, respectively, at this time. From August to November 2012, levels of ${ }^{134} \mathrm{Cs}$ and ${ }^{137} \mathrm{Cs}$ decreased to less than $2 \mathrm{~Bq} / \mathrm{l}$ and less than $3 \mathrm{~Bq} / \mathrm{l}$, respectively, in the water immediately above the lake bed (Ministry of Environment $2012 b, 2013 a)$. Thus, radiocesium concentrations decreased rapidly in the water of Lake Hayama during the first year after the fallout. 


\section{3 "Positive Size Effect" on Radiocesium Concentrations in Five Freshwater Fish Species}

The total length (TL) distribution for the five fish species is shown in Fig. 16.2. The TL of bluegill, Carassius spp., and Japanese dace ranged from 86 to $163 \mathrm{~mm}, 217$ to $461 \mathrm{~mm}$, and 220 to $374 \mathrm{~mm}$, respectively (Fig. 16.2). Both largemouth and smallmouth bass had a wider range of TL, 80-545 $\mathrm{mm}$ and 79-457 $\mathrm{mm}$, respectively (Fig. 16.2). Because we used gill nets to capture fish, it is likely that small Carassius spp. and Japanese dace (TL $<200 \mathrm{~mm}$ ) were not captured. Conversely, small bluegill, smallmouth bass, and largemouth bass have a high body height so are

Fig. 16.2 Total length (TL, $\mathrm{mm}$ ) distribution for bluegill (a), Carassius spp. (b), Japanese dace (c), largemouth bass (d), and smallmouth bass (e)

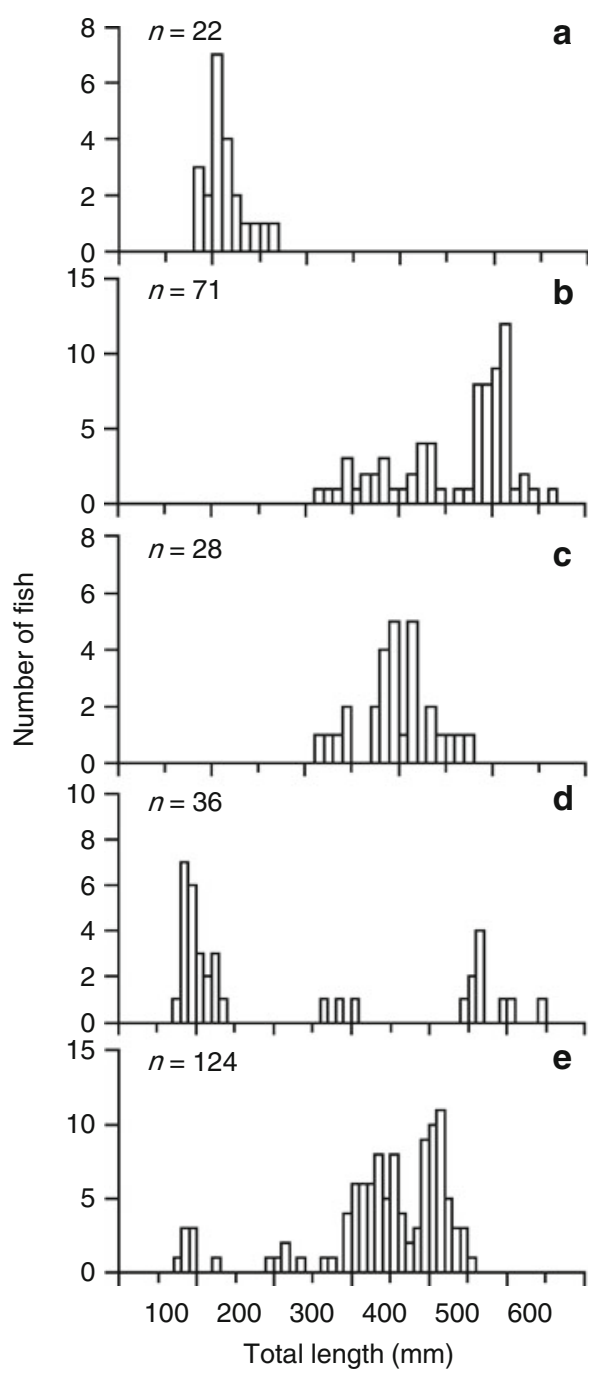


more susceptible to capture in our gill nets. The small-sized Carassius spp. and Japanese dace represent younger fish including age 0 and 1 (Suzuki and Kimura 1977; Liu et al. 1986; Ishizaki et al. 2009).

Judging from our data and the information of age and growth for largemouth and smallmouth bass (Yodo and Kimura 1996; Nakamura et al. 2004), we assume that the samples of these two species included age 0 and older fish. The bluegill we captured were likely older than age 0 , although their growth varies considerably with population size structure (Drake et al. 1997; Belk 1995). Taken together, these observations suggest that we obtained both age 0 and older fish only for largemouth and smallmouth bass.

The radiocesium $\left({ }^{134} \mathrm{Cs}+{ }^{137} \mathrm{Cs}\right)$ concentrations were generally lower in smaller fish than in larger fish (Fig. 16.3). The natural log of radiocesium concentrations

Fig. 16.3 Relationship between total length (TL) of fish and radiocesium $\left({ }^{134} \mathrm{Cs}+{ }^{137} \mathrm{Cs}\right)$ concentrations for bluegill (open triangles), Carassius spp. (crosses), and Japanese dace (open circles) (a), largemouth bass (b), and smallmouth bass (c). There was an exponential relationship between radiocesium concentrations and TL in largemouth bass (b) and smallmouth bass (c)

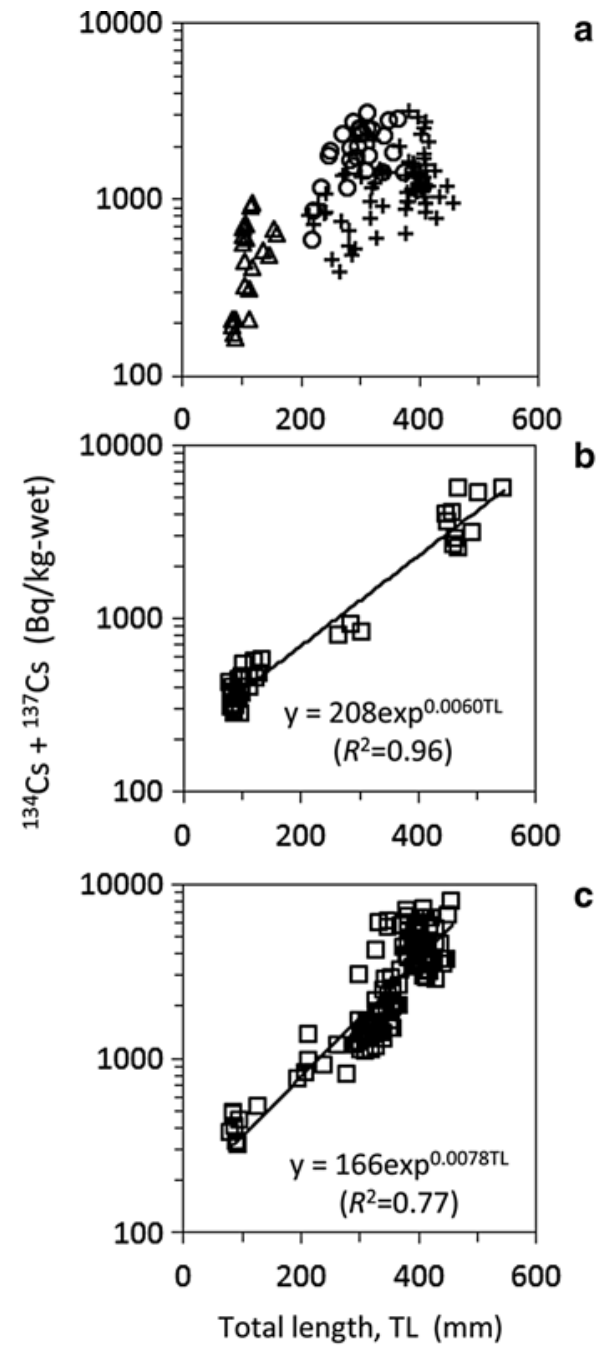


were positively but poorly correlated with TL for bluegill $\left(R^{2}=0.30, p<0.01\right)$, Carassius spp. $\left(R^{2}=0.23, p<0.01\right)$, and Japanese dace $\left(R^{2}=0.30, p<0.01\right)$, species for which we were unable to collect younger fish. Conversely, we observed a strong positive exponential correlation between TL and radiocesium concentrations in largemouth bass $\left(R^{2}=0.96, p<0.01\right)$ and smallmouth bass $\left(R^{2}=0.77, p<0.01\right)$ (Fig. 16.3).

\subsection{Influence of Diet on Radiocesium Concentrations in Freshwater Fish}

Both younger and older fish are needed to detect the positive size effect described by Kryshev and Ryabov (2000). We found evidence for a positive size effect in carnivorous bass, the only species for which we were able to obtain both young and old individuals. We compared the radiocesium levels in fish from different trophic positions, although we only collected older individuals from omnivorous and herbivorous species.

The geometric mean radiocesium concentrations by body size class (interval of $100 \mathrm{~mm}$ TL) for each species are given in Table 16.1. The geometric mean radiocesium concentration in each size class $(n>2)$ was higher for carnivorous fish than for omnivorous or herbivorous fish, suggesting that trophic position is an important determinant of species-specific concentrations. Only two exceptions to this pattern were observed, in bluegill in the $100 \mathrm{~mm}<\mathrm{TL} \leq 200 \mathrm{~mm}$ size class, and in Japanese dace in the $200 \mathrm{~mm}<\mathrm{TL} \leq 300 \mathrm{~mm}$ size class. Such exceptions may be a function of different life stages; adult (older) omnivorous and herbivorous fish have higher levels than younger carnivorous fish.

We speculate that the larger largemouth and smallmouth bass individuals, which had relatively high radiocesium concentrations, were adults at the time the FNPP accident occurred. These individuals have likely preyed continuously upon radiocesium-contaminated insects and fishes since the time of the accident. Because of their low rate of metabolism, much of the radiocesium was retained within their body during the year following the fallout. In contrast, smaller bass ( $\leq 200 \mathrm{~mm} T L)$ were likely juveniles ( 1 year old or younger), larvae, eggs, or did not exist at the time of the FNPP accident. Even if these younger individuals consumed highly contaminated prey items after the fallout from the FNPP, they would still likely have lower radiocesium concentrations than older fish because of their high metabolic rate and dilution resulting from tissue growth.

The radiocesium concentrations in fish were variable, but generally high in the diet items of omnivorous and herbivorous fish, such as bluegill, Carassius spp., and Japanese dace in 2012. Radiocesium concentrations in Spirogyra and aquatic insects fluctuated from 94 to $1,870 \mathrm{~Bq} / \mathrm{kg}$ wet weight and from 92 to $1,100 \mathrm{~Bq} / \mathrm{kg}$ wet weight, respectively (Ministry of Environment 2012c, 2013b, c, d). Thus, the concentration of radiocesium in Spirogyra was as high as in small fish $(\leq 200 \mathrm{~mm}$ $\mathrm{TL}$ ) in our study (Table 16.1). Given this, even herbivorous Carassius spp. are susceptible to radiocesium. 


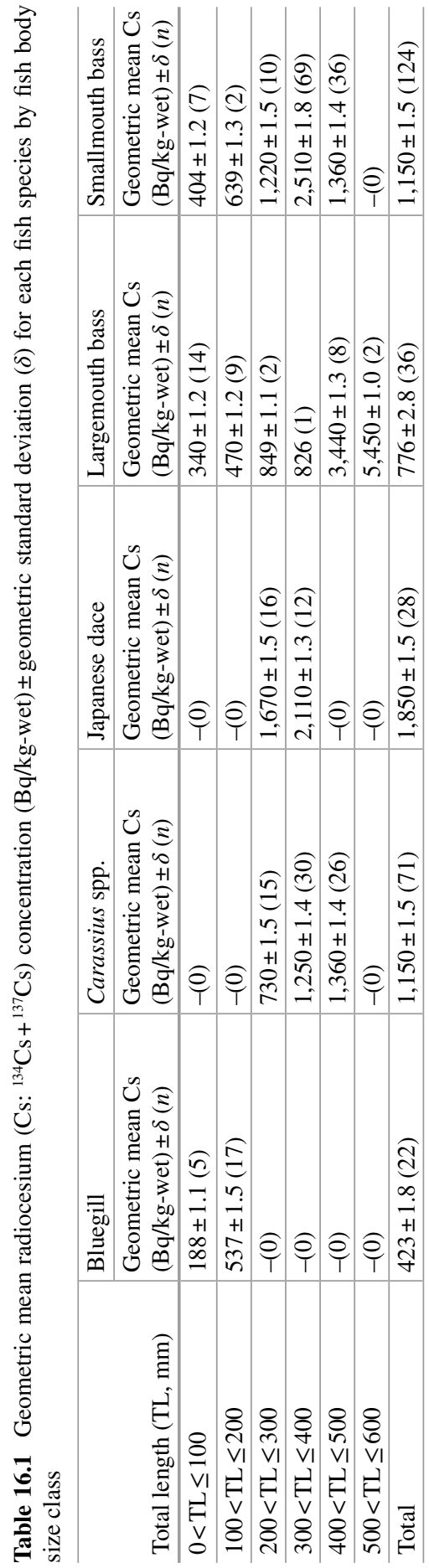


Lake Hayama was located in the zone of high radiocesium deposition, so fish are likely exposed to radiocesium from the surrounding forest ecosystem. Compared with European forests, the forests in Japan experience a warmer climate with higher mean annual precipitation. These differences make it likely that Japanese forests will circulate radiocesium deposited by the FNPP accident more rapidly than did the European forests following the Chernobyl accident (Hashimoto et al. 2013). Indeed, the levels of radiocesium in trees dropped rapidly during the first 2 years after the fallout, but radiocesium in the soil surface organic layer and soil surface layer $(0-5 \mathrm{~cm})$ components kept the same level during 2012-2013 (Forestry Agency 2014). During this period, fish in Lake Hayama were likely exposed to radiocesium from the organic components of the surrounding forest through the food web. Further monitoring of radiocesium concentrations in fish (including information on body size and age) is needed to predict the long-term dynamics of radiocesium concentrations in fish.

Acknowledgments This chapter was written based on Takagi et al. (accepted).

Open Access This chapter is distributed under the terms of the Creative Commons Attribution Noncommercial License, which permits any noncommercial use, distribution, and reproduction in any medium, provided the original author(s) and source are credited.

\section{References}

Belk MC (1995) Variation in growth and maturity in bluegill sunfish: genetic or environmental effects? J Fish Biol 47:237-247

Butler D (2011) Radioactivity spreads in Japan. Nature (Lond) 471:555-556

Chino M, Nakayama H, Nagai H, Terada H, Katata G, Yamazawa H (2011) Preliminary estimation of release amounts of ${ }^{131} \mathrm{I}$ and ${ }^{137} \mathrm{Cs}$ accidentally discharged from the Fukushima Daiichi nuclear power plant into the atmosphere. J Nucl Sci Technol 48:1129-1134

Drake MT, Claussen JE, Philipp DP, Pereira DL (1997) A comparison of bluegill reproductive strategies and growth among lakes with different fishing intensities. N Am J Fish Manag 17:496-507

Elliot JM, Hilton J, Rigg E, Tullett PA, Swift DJ, Leonard DRP (1992) Sources of variation in post-Chernobyl radiocaesium in fish from two Cumbrian lakes (northwest England). J Appl Ecol 29:108-119

Forestry Agency (2014) The results of distribution survey of radioactive materials in the forest [fiscal year 2013] (1 Apr 2014). Available via http://www.rinya.maff.go.jp/j/press/ken sidou/140401.html. Accessed 17 Nov 2014 (in Japanese)

Hashimoto S, Matsuura T, Nakano K, Linkov I, Shaw G, Kaneko S (2013) Predicted spatiotemporal dynamics of radiocesium deposited onto forests following the Fukushima nuclear accident. Sci Rep 3:2564. doi:10.1038/srep02564

Ishizaki D, Otake T, Sato T, Yodo T, Yoshioka M, Kashiwagi M (2009) Use of otolith microchemistry to estimate the migratory history of Japanese dace Tribolodon hakonensis in the Kamo River, Mie Prefecture. Nippon Suisan Gakkaishi 75:419-424 (in Japanese)

Koulikov AO, Ryabov IN (1992) Specific cesium activity in freshwater fish and the size effect. Sci Total Environ 112:125-142

Kryshev AI, Ryabov IN (2000) A dynamic model of ${ }^{137} \mathrm{Cs}$ accumulation by fish of different age classes. J Environ Radioact 50:221-233 
Liu H, Shimazaki K, Mishima S (1986) Biological studies on Ugui-dace Tribolodon hakonensis (Günter) in the Ohno River, Hokkaido, Japan: I. Early development and character of scales different locations. Bull Fac Fish Hokkaido Univ 37:23-29

Ministry of Environment, Government of Japan (2011) The results of radioactive material monitoring of the surface water bodies within Fukushima prefecture (November 15, 2011). Available via http://www.env.go.jp/en/water/rmms/surveys.html. Accessed 7 Nov 2014

Ministry of Environment, Government of Japan (2012a) Extension site of distribution map of radiation dose, etc./Digital Japan. Available via http://ramap.jmc.or.jp/map/eng/map.html. Accessed 7 Nov 2014

Ministry of Environment, Government of Japan (2012b) The results of radioactive material monitoring of the surface water bodies within Fukushima prefecture (July-September samples). Available via http://www.env.go.jp/en/water/rmms/surveys.html. Accessed 7 Nov 2014

Ministry of Environment, Government of Japan (2012c) The results of radioactive material monitoring surveys of aquatic organisms (2012 spring samples). Available via http://www.env.go.jp/ en/water/rmms/result_ao02-part.html. Accessed 7 Nov 2014

Ministry of Environment, Government of Japan (2013a) The results of radioactive material monitoring of the surface water bodies within Fukushima Prefecture (September-November samples) (January 10, 2013). Available via http://www.env.go.jp/en/water/rmms/surveys.html. Accessed 7 Nov 2014

Ministry of Environment, Government of Japan (2013b) The results of radioactive material monitoring surveys of aquatic organisms (2012 summer samples). Available via http://www.env. go.jp/en/water/rmms/result_ao02-part.html. Accessed 7 Nov 2014

Ministry of Environment, Government of Japan (2013c) The results of radioactive material monitoring surveys of aquatic organisms (2012 fall samples). Available via http://www.env.go.jp/en/ water/rmms/result_ao02-part.html. Accessed 7 Nov 2014

Ministry of Environment, Government of Japan (2013d) The results of radioactive material monitoring surveys of aquatic organisms (2012 winter samples). Available via http://www.env.go.jp/ en/water/rmms/result_ao02-part.html. Accessed 7 Nov 2014

Nakamura T, Katano O, Yamamoto S (2004) Effect of water flow and water temperature on the growth of smallmouth bass Micropter duoslomiez and largemouth bass M. almoides. Nippon Suisan Gakkaishi 70:745-749 (in Japanese)

Rask M, Saxén R, Ruuhijärvi J, Arvola L, Järvinen M, Koskelainen U, Outola I, Vuorinen PJ (2012) Short- and long-term patterns of ${ }^{137} \mathrm{Cs}$ in fish and other aquatic organisms of small forest lakes in southern Finland since the Chernobyl accident. J Environ Radioact 103:41-47

Saxén R, Koskelainen U (1992) Radioactivity of surface water and freshwater fish in Finland in 1988-1990. Suppl 6, Ann Rep STUK-A89. Helsinki, pp 1-75

Smith JT, Kudelsky AV, Ryabov IN, Daire SE, Boyer L, Blust RJ, Fernandez JA, Hadderinfh RH, Voitsekhovitch OV (2002) Uptake and elimination of radiocaesium in fish and the "size effect". J Environ Radioact 62:145-164

Suzuki K, Kimura S (1977) Growth of the crucian carps belonging to the genus Carassius in the lower reaches of the Nagara River, central Japan. Jpn J Ichthyol 24:199-206

Takagi K, Yamamoto S, Matsuda K, Tomiya A, Enomoto M, Shigenobu Y, Fujimoto K, Ono T, Morita T, Uchida K, Watanabe T (accepted) Radiocesium concentrations and body size of largemouth bass, Micropterus salmoides, and smallmouth bass, M. dolomieu, in Lake Hayama, Japan. J Appl Ichthyol

Tokyo Electric Power Co., Inc (2012) Press release (May 24, 2012), The estimated amount of radioactive materials released into the air and the ocean caused by Fukushima Daiichi nuclear power station accident due to the Tohoku-Chihou-Taiheiyou-Oki earthquake (As of May 2012). Available via http://www.tepco.co.jp/en/press/corp-com/release/2012/1204659_1870.html. Accessed 2 Apr 2015

Yodo T, Kimura S (1996) Age and growth of the largemouth bass Micropterus salmoides in Lakes Shorenji and Nishiko, central Japan. Fish Sci 62:524-528 